\title{
Making community development at grassroots reality: Church-driven development approach in Zimbabwe's context of severe poverty
}

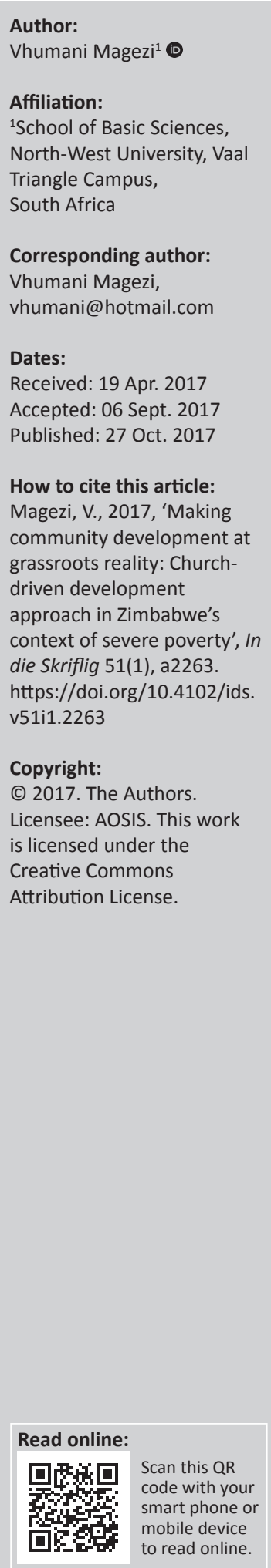

The critical role played by communities in development initiatives is globally acknowledged. Churches are key community institutions that play a crucial role in community development, yet their role is not well understood from an empirical perspective. A cross-sectional study of a church-driven community development initiative that was implemented in line with a practical inquiry approach, was conducted. The findings are presented and discussed, thereby leading to the conception of a holistic church-driven development approach that brings together different churches in the community. This approach responds to integrated community needs without focusing on one single issue, which is different to approaches advocated by some international development agencies and donors who recommend one or a few focused interventions.

\section{Introduction}

Churches and other faith based organisations (FBOs) play a critical role in community development. However, due to different religious and ideological positions held by FBOs (churches), their potential contribution to effective community development is hindered by poor coordination and limited capacity to organise themselves to work together. The questions that arise amongst others are: Considering the coordination capacity gap and limited resources, how could churches perform a meaningful community development role amongst many poor African communities such as in Zimbabwe? Can there be a practical approach that could be employed to leverage the community position of churches to ameliorate suffering amongst the poor people? This article responds to these questions by describing a case study of a facilitated model that harnesses churches' potential in communities. The model highlights the extent that church stakeholders and congregations can focus on vivid community needs as a motivation and glue for a church-driven community development approach within African contexts of poverty such as in rural Zimbabwe. While the study was in the form of a development program, it justifiably falls within the category of implementation research. Peters et al. (2014:1) in their insightful article, Implementation research: What it is and how to do it, observe that implementation research is a growing but not well understood field'. Woolsey and Biebel (2007) describe implementation research as:

a black box, providing information about the journey from research theory to actual practice. Implementation studies examine issues of design, administration, and operation by tracking day-to-day, 'real world' events. (p. 3)

Peters et al. (2014:3) guide that, amongst other things, implementation research is to identify and describe the implementation dynamics in a given context through methodologies that include a case study. Therefore, this study focuses on describing the discerned model in a real world where there is flux.

\section{Study background}

The role of communities in leading community responses has gained significant recognition in the last decade and more prominently in the last five years. One critical player in community responses are faith-based organisations (FBOs), particularly churches. The huge burden on communities, due to the challenge of HIV has provided an important nexus through which the role of communities has been understood. Birdsall and Kelly $(2005: 8,10)$ and Kelly, Asta, and Stern (2010:42) in their work at the Centre for AIDS Development Research and Evaluation in South Africa, in addition to Foster (2010:3-5), amongst others, have researched communities and have all unequivocally concluded that communities play a key role in responding to community needs. However, a greater part of the work of these scholars can be characterised as impressionistic and 
micro or localised. Impressionistic work has tended to reflect on the work of communities and churches in an arguably romanticised way with little or no empirical research. The work of Parry (2003:13-14) and the World Council of Churches (2010:6) in HIV responses, albeit informative, fit in this category. The empirical research that has been conducted is localised to few communities, one country or very few countries in a continent. This, therefore, can be characterised as micro-work. The work of Birdsall and Kelly (2005:10) and Kelly et al. (2010:42) at the Centre for AIDS Development Research and Evaluation in South Africa fit into this category. Even though their work stretches to several other countries, the scope has not necessarily been global.

However, an observation that can be made in the study of communities in the last five years has been the shift from impressionistic and micro scale to global scale. Magezi (2012:1) notes that the 19th International Aids Conference (22-27 July 2012) in the USA (Washington DC) had very clear urging towards community focus. The successor conference, the 20th International AIDS Conference in Melbourne (20-25 July 2014), further stressed the critical role of communities. Following up on the Melbourne resolutions and discussions, UNAIDS (2014) Eastern and Southern Africa (ESA) held a CSO Community Dialogue to explore ways of sustaining community responses beyond 2015 .

Simms (2013:S1) explained that the role of communities is clearly highlighted by the ground-breaking 2011 UNAIDS Strategic Investment Framework that calls for increased community involvement. With momentum gathering on the contribution of communities, although the role is poorly appreciated and not clearly understood, the World Bank and DfID (now UK AID) commissioned an extensive evaluation. This recent evaluation reveals information on the role of communities that addresses scepticism of impressionism and localised focus. The results of the evaluations are reported in the manuscript, Direction in development: Investing in communities achieves results, published by World Bank. Rodriguez-Garcia et al. (2013:1-3), the authors of the manuscript, explained that the evaluation is based on 15 studies and 11 existing evaluations conducted in eight countries. To date, this has been the most comprehensive study of its kind on the role of communities. The evaluations used a variety of methodologies, instruments and settings to collect and analyse data on communities. The findings of the study revealed that communities function with very little resources. Despite limited resources, communities engage in innovative community strategies that ameliorate the suffering of its members. Reporting in the context of HIV, the report indicates that communities help mobilising resources; significantly improve knowledge of people; increase the use of services; and affect outcomes of social processes. Gender and stigmatisation proved to be inconclusive.

These afore-mentioned findings confirm the findings of several earlier studies conducted by scholars such as Birdsall and Kelly (2005:8), Foster (2010:3-5), Kelly et al. (2010:42), and many others who highlighted the critical role of communities.
Therefore, governments and UN organisations explicitly refer to the role of communities such as the 2011 UNAIDS Strategic Investment Framework, The South African HIV and AIDS and STI National Strategic Plan (NSP), Alma Ata Declaration of 1978, and Zimbabwe WHO PMTCT Strategic Vision 20102015, just to name a few. With communities playing a crucial developmental role, it is imperative to identify the different categories of community structures and determine their roles. Rodriguez-García et al. (2013:4) described community responses as having six main categories, one of which being the type of implementing organisations and structures. From this description, one major category of community responses based on implementing organisations and structures flows, namely Faith-Based Organisations (FBOs). Birdsall and Kelly (2005:8) and Kelly et al. (2010:42), in their study of organisations operating at grassroots community level in South Africa, observed that a significant number of the organisations were FBOs. Foster's (2010) study revealed a similar trend across many Southern African countries where congregations and religious support groups constitute the majority (63\%) of community-level organisations. The World Council of Churches (2010:6) reported that World Health Organization (WHO) estimates that FBOs provide 30-70 per cent of health care in the developing world. Mati (2013:2) therefore correctly commented that FBOs are the most prominent manifestations of civil society in Africa. He added that FBOs have been playing a key role in African development, and this situation will continue for many years to come. However, Mati (2013:2) laments the inadequate attention given to FBOs in social scientific analysis.

To proceed with the study analysis, it is important to understand the information gap on FBOs (churches) to ensure the model is located within a theoretical framework.

\section{Information gap on FBOs' (churches) developmental role}

In order to address the above (research) questions, it is critical to sketch the state of FBOs (churches) in development to contextualise the discussion as well as establish the situation. While there is general scepticism on the role of FBOs in development, there is increasing observable interest on their role. James (2009b:8) rightly observed that there is resurgence of interest in the developmental role of faiths, even in such non-spiritual organisations as the World Bank. FBOs, as civil society organisations, ignite civil society advocacy. James (2009b:7-9) added that the important historical and current contribution of churches in advocacy is also increasingly recognised as has been seen in the past with civil rights movement in the USA and democratisation in Latin America. As such, FBOs form a critical part of the third sector field.

Despite the acknowledgement of the role of FBOs (churches) noted above, Samuels, Geibel and Perry (2010:1) agree with Mati (2013:2) that FBOs have not been seriously explored. They note that this is partly because some humanitarian organisations do not value the role of FBOs that much. While Samuels et al. (2010) argue that the oversight of FBOs' 
importance is a result of the weak view of some humanitarian organisations, there are more reasons to this issue. The ambivalent role of FBOs should be noted. Mati (2013:1-3) observes that while FBOs have been instrumental in addressing the needs of community people, they have also been used by religious fundamentalists and extremists to the detriment of society. Some groups of people have used faith to support gender based violence and other forms of violence such as the Boko Haram in Nigeria. There has also been a concern of a blurred line between development work by FBOs and proselytising people using the same resources. Notwithstanding these concerns about FBOs, Samuels et al. (2010:1-4) report that there is evidence in many situations that FBOs provide better quality services than government.

Mati (2013:2) and Samuels et al. (2010:1) usefully observed that FBOs have not been significantly explored and socioscientifically analysed. This has tended to result in the amplification of FBOs and churches' altruism. The analysis gap is clearly notable in at least two areas, namely the confusion of the operational usage of the word church, as well as the uncritical and confusing usage of the term FBOs to include churches and Christian based Non-Governmental Organisations (NGOs). Magezi (2012:4-5) traced part of the confusion of the use of the word church to its usage in sacred writings (Bible) whereby the word in daily use is used interchangeably in three ways. Firstly, it is used to refer to a local assembly or congregation, denomination and universal church. Secondly, it outlines the typology of churches' work in development. The first typology dictates that churches operate like government in the situation where government is in partnership with the church leadership bodies. For instance, government can pay salaries for all staff in schools or hospitals while the church retains control of who to place in the institutions. The second typology is where the church has a diakonia department. Denominations such as the Roman Catholic, Anglicans, Methodists and many others have church development desks responsible for sourcing resources and distributing them to communities. The third typology refers to the congregational ecology where a local assembly arises to respond to community needs in an organic way. Because sociologically the church is a subsystem of society, church members also feel the sting of community challenges. The final typology involves churches that refuse to participate in development matters, and they separate church and development issues.

James (2009b:12) developed a typology of FBOs that falls into three categories. First is the church arm, called the FBO responsible for development within a religious institution in the sense of Magezi's (2012:5) denomination diakonia. There is no separate legal registration between the FBO and the religious institution. The second category is where development work (FBO) partially takes place within the religious institution. In this case, there is some level of independence of the development arm, but church leadership has considerable control. The FBO may have a separate registration. Third is development work outside of religious institutions. The development work (FBO) is independent with its own registration and other external networks. James (2009a:12-13) advises that the relationship between a church and the church development agency, which he calls an FBO, should be understood in order to function optimally in respective environments.

Samuels et al. (2010:1-4) cited three UNAIDS categories of FBOs, viz. informal social groups or local faith communities such as women or youth groups; formal religious communities with an organised hierarchy and leadership such as Muslims, Hindus or Christians with sub-divisions such as Catholic Christianity; and independent faith-influenced nongovernmental organisation such as Islamic Relief and Tearfund, as well as networks such as the Ecumenical Advocacy Alliance and Caritas International.

The UNAIDS categorisations broadly account for the diverse forms of FBOs while James (200b9:12-13) focuses on FBOs formation within a religious institution. While the UNAIDS categories are inclusive, they are not useful for analytic purposes. James' focus on FBO structures within the institution overlooks the mutual in-exclusiveness and integration of religious communities in development actions. In many cases, churches engage in development as a religious institution without necessarily having another internal structure, which he calls the FBO. With these gaps, Mati's (2013:2) lament is understandable that FBOs have not seriously been subjected to rigorous social scientific analysis. Magezi's (2012:4-5) typologies are an effort to bring down seemingly 'in the air' discussion of FBOs by first separating church based development from general FBO work. Churches are FBOs, but FBOs are not churches, ${ }^{1}$ for instance independent Christian influenced organisations like Tearfund and Ecumenical Advocacy are not churches. Subchurch groups such as youth and women's groups are not churches but part of the church. From this description of church and understanding its possible community role, Magezi (2012:6-7) recommends an understanding and analysis of a church response based on the congregational ecology approach. In this approach, churches respond to community needs as part of a community structure and system. The congregation and the community join hands in addressing common community problems.

An observation that has been made by many researchers is that communities lack financial resources (World Council of Churches 2010:6). Kelly et al. (2010:42) indicate that funders do not make valuable commitments to strengthen communities. Birdsall and Kelly (2005:8) and Rodriguez-Garcia et al. (2013:13) observe that in addition to funding constraints, communities have poor coordination and integration, require capacity development and funding or resource mobilisation approaches that are suitable for local level support. James (2009a:12-13) emphasises the importance of relationships amongst churches in their work in communities. Rodriguez-Garcia et al. (2013:1-3) recommend that for community responses to be effective,

1.Church here is taken to refer to an institution located in a geographical community rather than general people who believe in Jesus. In this case, the church (whether rather than general people who believe in Jesus. In this case, the church (whether
with or without a building) is a community structure. It is a system that mobilises people and glues them together on the basis of their faith belonging. 
targeting of community needs should be improved; community activities should be aligned; and complementarities should be strengthened. Therefore, while community based responses are hailed as a critical sustainable development approach, their weakness makes potential supporters cringe. For churches a further challenge is the doctrinal differences and consequent relationship challenges that arise from it.

With communities having multiple local church assemblies, the dilemma of harnessing the various churches' capacities in a community to a common development issue arises. It is important to overcome the churches' silo and competition mentality by shifting them to focus on complementing one another as well as focus on a prioritised community need. Therefore, the question that is posed to shape the discussion towards this goal is: What could be a practical approach that can be employed to leverage on the community position of churches to ameliorate suffering amongst the poor people? In response to this question, a facilitated model that harnesses churches' potentials in communities and focuses church stakeholders or congregations on vivid community needs is proposed as a church-driven community development model within African contexts of poverty in rural Zimbabwe. The methodology for such an approach is described in the next section ('Methodology and context') in the form of a case study.

A case study is a useful methodology that allows in-depth, multi-faceted explorations of complex issues in their real-life settings. It is a form of qualitative descriptive research that focuses intensely at an individual or small participant pool, drawing conclusions only about that participant or group and only in that specific context. Researchers do not focus on the discovery of a universal, generalisable truth, nor do they typically look for cause-effect relationships; instead, emphasis is placed on exploration and description (Colorado State University 2016:3; Crowe et al. 2011:2). Despite criticism that case study methodology focuses on a small number of cases, it offers no grounds for establishing reliability or generality of findings. However, researchers view it as an important methodology that provides a detailed understanding of a phenomenon or case. In this article the case study is employed because of its ability to provide detailed appeal and understanding to the various dynamics of church community interactions, as well as dynamics that may not be captured in the same way if other methodologies were used.

\section{Methodology and context Church development initiative - practical inquiry}

A church-driven community development project was operationalised $^{2}$ even though it was not necessarily as an academic research project. The establishment merits analysis from a practical inquiry perspective as an implementation research. A practical inquiry approach is rooted in pragmatist philosophy. It aims at generating knowledge for local people 2.The names of organisations are withheld to maintain anonymity. as well as general practice. Göran (n.d) explains that while a practical inquiry approach shares similarities with action research, there are differences. He further elaborates that the purpose of a practical inquiry is, through empirical study on practical matters in local practices, to contribute to general practical knowledge. Stevenson (2005) contrasts practical inquiry with positivist inquiry approaches by noting that positivist approaches produce theories that are detached from the practical situations of people and lack relevancy to everyday practice; practical inquiry, on the other hand, generates practical knowledge in the fluidity and flux of practical daily realities. He adds that practical theory is judged in terms of whether or not it helps people to 'go on' with their lives. Thus, even though the project was not necessarily an academic study per se, its implementation conformed to a practical inquiry approach.

An area to implement a church-driven community development project (HIV and development) over five years was identified and mapped in the rural community of Masvingo Province of Zimbabwe called Bikita. Bikita district is located about $80 \mathrm{~km}$ east of Masvingo town. The place is mountainous with steep slopes, sandy-loamy soils and was hit by drought in 1994, 2002, 2004 and 2008. Mushore, Mudavanhu and Makovere (2013) indicate that the area covers approximately $10000 \mathrm{~km}^{2}$, and has a population of around 200000 people. It is also to be noted that $81 \%$ of the district is classified as belonging to the natural regions (4 and 5) with mean annual rainfall ranging from $400 \mathrm{~mm}$ to 700 $\mathrm{mm}$. According to the Zimbabwe Vulnerability Assessment Committee (ZimVac) (2010), the district is one of the poorest in the country.

Project funds were provided by an overseas Christian organisation to a Zimbabwe local Christian organisation (NGO) to lead in program facilitation. A database of churches in the area was developed. A total number of 102 local assemblies were identified (local assembly refers to a congregation in a community). If the Methodist denomination, e.g. has a congregation in the community, it will be counted as one; if it has two, then it will be counted as two. The emphasis was the rootedness of each church assembly in the community. A community refers to people sharing a geographic sense of place (a group in a location or an administrative entity). The churches (church assemblies) were drawn from the churches present in the community.

The churches fell into three categories, namely mainline, Pentecostal and African independent churches. Mainline churches are those that were started by missionaries and have their roots in the reformed tradition. Pentecostal churches are those churches that emphasise manifestation of spiritual gifts. African Independent churches are churches that are sometimes called White garment churches that do not worship in church buildings. Church leaders in the community were trained on the project. The training covered general aspects such as developing work plans, managing activities, managing community relationships, mobilising community as well as the implementation of activities. The 
facilitating Christian organisation provided in-community site mentoring and coaching to the church leaders. Leaders from different churches conducted joint community activities within their congregations to create a platform for sharing ideas and skills, thereby promoting team spirit. Different church members had opportunities to share experiences, and church leaders facilitated community-envisioning sessions to address the needs of the community. The church leaders also convened church and community meetings. Church leaders further conducted training on community mobilisation to all church members to ensure that all members in the community have knowledge and skills to mobilise one another.

The facilitator, together with church leaders, church and community members outlined the change they needed to see in the community. They specified the short-term, mediumterm and long-term community goals. A steering committee was elected to lead the community development initiative. The church leaders, their members and community people regularly met and reflected on the project; adjusted the project deliverables; as well as ensured that milestones were achieved.

\section{Study assessment design}

This study was a cross-sectional assessment of a churchdriven community development program outlined in the above section (Church development initiative - practical inquiry') after four years. The research design for the empirical study falls within an interpretivist paradigm. In an interpretivist paradigm, the researcher describes and interprets phenomena in order to derive meaning from the situation. An interpretivist paradigm holds to a constructivist philosophical position whereby complexities of the sociocultural world are experienced, interpreted and understood in a particular context (Babbie \& Mouton 2003; Marshall \& Rossman 2006; Maxwell 2005). An interpretive paradigm aims to discover and describe and is generally focused on extracting and interpreting the meaning of experience. The researcher entered the world of others and thereby attempted to achieve a holistic rather than a reductionist understanding of the program as it relates to community development amongst poor people.

The data was collected using a semi-structured questionnaire with the program facilitator, coordinating committee and community leaders. Focus group discussions were also held with various church groups involved in the project. The questions and discussions focused on the following: How do the different churches with different theological and ideological positions partner in community projects from a church perspective?; How do the churches coordinate themselves to respond to community needs?; How are the churches accessing resources to address community needs?; How are the churches working together with community people who are not Christians?; How are the churches practically contributing to the lives of people in the community?; How can the church be used and engaged on an ongoing basis to reduce suffering in the community?; and
How do the churches succeed and how do the success factors in the church lead community initiative?

A document analysis of program documents was also conducted. The above questions were used as basic frameworks or codes followed by detailed analysis under each framework, using a grounded approach. Documents were analysed using a content analysis. Triangulation was done by comparing the findings from interviews with program documents; constant comparison and member validation; and consideration of negative cases during interviews. Babbie and Mouton (2003) explain negative cases as cases whereby researchers constantly looks for cases, settings and events that are out of line with their main findings, or even that directly contradict their explanations and then respond to such cases. Constant comparison is checking the consistency and accuracy of interpretations and especially the application of codes by constantly comparing one interpretation or code with others, both of a similar sort and in other cases and settings. This ensures both consistency and completeness in analysis.

\section{Presentation of results}

The results from the study are presented below.

\section{Partnership of churches with different theological and ideological positions in community projects to address common needs}

Community participants acknowledged the multiplicity of churches in the community. They noted that the churches are fragmented but that community people are well integrated. While churches belong to various groupings, community people viewed themselves as one because they exist in the same community. In view of the fragmentation of churches, respondents reported that they were bonded to the project by a sense of 'equality, openness to each other, unconditional regard and respect for each other as neighbours in the community'. Thus, despite the differences in theological and church traditions, the churches emphasised equality, openness, unconditional regard for each other, and respect for each other, which was not only preached but also demonstrated. Equal space was provided to all churches in community meetings to share their practices and the way they conduct worship. This resulted in that the various churches appreciated one another and developed into a cohesive community unit. These community church meetings also provided space for sharing and learning from each other. The project facilitator reported: 'The meetings platform made the churches realise that besides their different theological persuasions, they can meet together and share the Word of God as well as address community concerns.'

Whenever meetings were held in the community amongst different churches, the agenda and focus was on community needs. These needs were not theoretical but were shared experiences of church people who live in those communities. Since church members are part of life's experiences in communities, they focused on pertinent community issues 
rather than petty theological divisive issues. Some focus group members reported that 'a sense of purpose and community needs' bonded them together.

Community church proceeded from commonly agreed community issues that need to be addressed. From these common issues, the discussions then evolved to other issues. Framing discussions on common agreed issues enabled potential non-cooperating members to have a clear perspective of the community needs before them. The respondents stated that 'discussions started from common ground of poverty and suffering of women and children in the community and then explored ways to address the issues in an objective way'.

Inclusive approaches used during meetings explored common ground across different churches. The establishment of common ground ensured that church members were bound by common interests based on common community experiences. As people were familiar with each other in the community, all members realised the need to act on the identified needs. One person responded as follows:

'All of us church people belong to this community. We have to wake up to the reality that if we don't do something, no one will do it for us. We should realise that the government is bankrupt.' (Participant 2, Male, 45 years old)

However, working with different church people required patience and tolerance. Some of the churches had reservations about working together, but through united effort across various churches in the community, they were encouraged to join the initiative. The community members rightly observed that

' $\ldots$ at the beginning, some churches were suspicious and didn't want to participate. But as time progressed, more and more churches joined and were now actively participating in the various community initiatives.' (Participant 6, Male, 32 years old)

\section{Coordination of churches to respond to community issues}

A coordination mechanism for all churches in the community was handled through a fraternal. A fraternal is an association of pastors, elders, deacons, and deaconesses from different denominations who make a wilful effort to join hands. They are bound by friendship, and honour common interest, and mutual interest. In the areas where there was no fraternal, a coordinating church committee was elected by church representatives from different denominations. A fraternal and a coordinating committee had the same functions. Representatives from the committee or fraternal representatives persuaded different churches to work together. This entailed communicating the vision of the community development initiative to those who may have lacked vision clarity, responding to people's concerns and providing a link between individual churches to the coordination mechanism. The focus group participants reported that the fraternal or committee individuals perform a critical function. They are the church and community information reservoir. They speak and answer all questions or enquiries regarding the functioning of the churches in the community. If you don't know what is happening, you go to them.' (Participant 7, Female, 36 years old)

The committee and fraternal members were bound by the love of Jesus Christ (Phlp 4:13). Their role extended beyond looking after the needs of people belonging to their own churches to the entire community. The fraternal or committee is a vehicle or mechanism that linked the churches and the rest of the community. The focus group participants and fraternal committee members explained that:

'The fraternal or coordinating committee had a mandate to coordinate the affairs of the community and not only for church members. They have a huge linking role for the rest of the community.' (Participant 1, Male, 55 years old)

The mandate of the fraternal and committee sometimes extended beyond its local community to external relations, particularly with key government institutions. Their ability to link and represent communities to other external actors to share community vision and lobby for resources increased their recognition beyond the community. The church members reported that:

'The fraternal and committee members had increasingly become respected and were leading in persuading and encouraging positive community initiatives. For instance, they encouraged and persuaded many church leaders to adopt good health seeking behaviours among HIV positive church members especially from church denominations that used to object to drugs. The situation is now changing as we are witnessing members from different denominations openly and freely communicating, teaching and preaching on sensitive HIV and AIDS issues like discrimination, stigmatisation, transmission and preventative methods.' (Participant 11, Female, 42 years old)

It was noted that in many mainline churches, pastors tended to work in that church assembly for a few years and then transferred to another area. In many cases the pastors do not come from the community hence they stay only for a period determined by their denominations, i.e. usually for a few years. These disrupted church community activities if such pastors were only the main focus of church community activities. The coordinating team, therefore, trained and involved other church leaders like elders and deacons in addition to the pastor to ensure stability and sustainability, as these church members are permanent in the community. The church leaders reported:

'Our strategy to ensure that our community activities are not affected, is to make the pastor work with his leadership team. This way you know every church will always have members who know the activities.' (Participant 10, Male, 39 years old)

\section{Churches' practical contribution to the lives of people in the community}

Despite that the majority of church and community people living on less than $\$ 1$ per day, the coordinating committee 
managed to gather significant resources to provide practical assistance to orphans' and vulnerable children's desperate situations. The program records show that the churches were paying school fees to at least 10 primary school children at US $\$ 10$ per term for each child (i.e. $\$ 300$ per year). Stationery such as exercise books, pens and pencils were also distributed to the needy children.

Due to limited accommodation for expecting mothers in the community, there were a frequent occurrence of home deliveries. This was risky and compromised the health of mothers and children. In response, churches met, gathered resources and mobilised the rest of the community to construct a mothers' waiting shelter and a youth office at the community clinic. The churches and the wider community provided sand, water, bricks, labour and moral support. The health centre reduced distances travelled by expecting mothers to a health care delivery centre. The youth also used one of the rooms as a meeting place.

During community needs mapping, the churches noted the need for assisting people living with disabilities. People living with disabilities (PWD) are highly stigmatised and discriminated against. The churches initiated awareness and formation sessions as well as formed support groups for PWDs. Thus, PWDs were assisted to run livelihood projects and nutrition gardens to generate income to support themselves. These initiatives reduced stigma and discrimination for PWDs as they were integrated openly into community structures.

The community, through the influence of churches, confidently stood up and voiced their concerns to responsible government authorities. There was lack of adequate clean water and electricity at the community clinic, which prompted the church leaders to approach relevant government offices to address the situation. The focus group participants stated:

'We cannot sit here and look. There are things we can do as a community, but there are some we cannot do. We need government to help us, so we went to them.' (Focus Group 3)

\section{Church access to resources to address community needs}

With the majority of churches and community people being very poor, living under $\$ 1$ a day, the churches made various initiatives to generate resources to support fellow community people. They engaged in activities that included contributing clothes from their wardrobes, putting together food hampers for the needy, contributing to the construction and rehabilitation of community structures, starting income and lending schemes (ISALS), and generating resources from external sources.

The initiative to generate clothes was named 'search your wardrobe'. This entailed contributing clothes that they could give away whereby people had to search their wardrobes for second-hand clothes that would be distributed to the needy people. The clothes were distributed to orphans, the disabled, widows, teen mothers, and people living with HIV and to the elderly. The food hampers included items such as mealiemeal, vegetables and cooking oil. The food items were distributed to families who do not have enough food.

The churches were also involved in rehabilitating small community paths and roads leading to public areas such as clinics and schools to ensure that women and children may easily access the places with carts. Furthermore, the churches started income saving and lending (ISALs) schemes to improve the financial situation of poor households. One focus group participant who is a beneficiary of ISALS stated that before engaging in ISALs she couldn't afford school fees for her children. Some church leaders with external links and connections used their networks to generate community resources. The church leaders highlighted the following example of external resource mobilisation by church people:

'The pastor and founder of one church who is also Veterinary Officer in the ward successfully sourced assistance from one donor. He got fencing wire, 45 watering cans, 45 hoes, 45 rakes, 45 garden shovels and 3 spades. This equipment was used to construct a garden and other projects to help the rest of community people.' (Participant 8 , Female, 46 years old)

\section{Church working with community people who are not Christians}

The churches' coordinating committees and the fraternals were the mechanism responsible for linking churches with the rest of other community people who are not church members. The materials that are sourced were not reserved for church members only, but were for the benefit of the entire community. The church and community leaders worked together to identify and prioritise the most deserving needy community people. The facilitator explained that

'The fraternal or coordinating committee has a mandate to coordinate the affairs of the community and is used to mobilise church and community members for church and community led initiatives. The fraternal is there for the community when we come to community initiatives, but when we hold church meetings, they coordinate church meetings for church members.' (Participant 2, Male, 35 years old)

\section{Churches' success factors in community development initiative}

The reviewed documents and interview discussions held indicated a number of factors that made churches successful in community development initiatives. The success factors are summarised on the thematic map in Figure 1.

The factors that contribute to churches' success in community development, as indicated on the thematic map above (Figure 1), are closely linked and mutually reinforce each other for effective development initiatives. The substantive motivating and encouraging message of the Christian message addresses the holistic needs of human beings (physical, spiritual, emotional and social). The message and model of Jesus provides a standard that Christians should strive for. The presence of churches in the communities allows them to be accessed by communities; be in proximity with community 


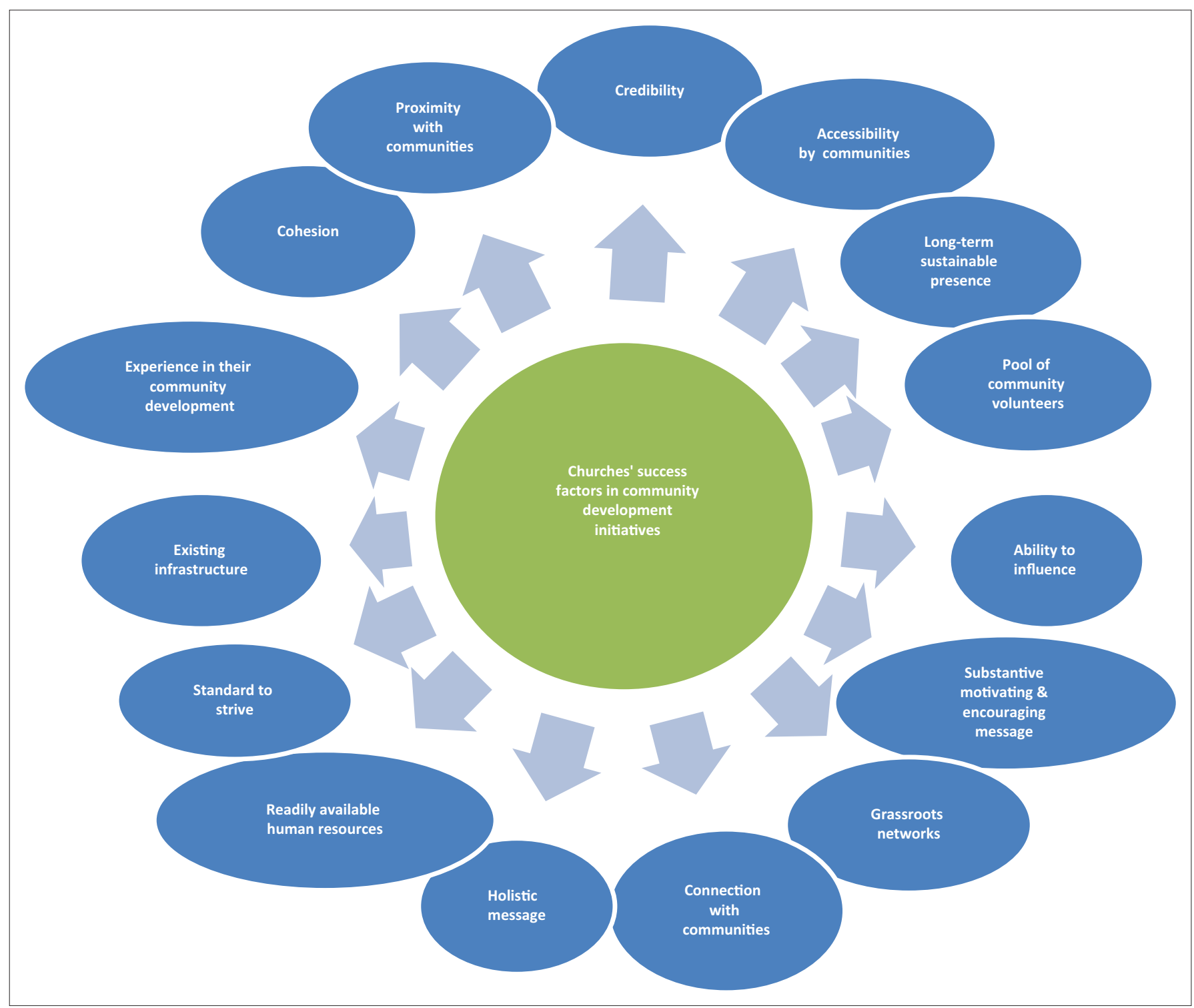

Figure 1: Success factors of churches in community development initiatives

people; connect with the community people; and develop grassroots networks of church and community members through their existing human and physical infrastructure and systems. By virtue of the respect they have in communities, the churches and their members are able to influence, forge and cultivate long-term sustainable relationships and structures between church and community members. Community people trust churches as credible institutions whereby members are a source of community volunteers and other human resources. There is cohesion amongst church members, particularly amongst those who belong to the same denomination or assembly. Church members, as community members, are also aware of the existing needs in the communities and possible responsive development solutions.

\section{Interpretation of results - churches in community development}

Development is a fluid term to define, and people conceive it differently. Cloete, Groenewald and Van Wyk (1996:10-20) conceded that development is a difficult term to define because what is accepted for one person as development might be interpreted by another as no development, or even as a decline. It entails value judgement. However, what Cloete et al. (1996) together with other scholars and practitioners agree upon is that development is often seen in conjunction with other terms such as change, growth, progress, reformation, transformation or even revolution (Anderson 1996:15-30; Cloete et al. 1996:10-20). Development should be seen in relation to a specific aspect of our existence in order to understand it. The aspect could be physical, economic, social or political. Anderson (1996:15-30), Davids, Theron and Maphunye (2005:18) and Kotze (1997:11-28), Rubin and Rubin (1986:12-25) and many other scholars view the basic ingredient of development to be change, not just any change, but a definite improvement - a change for the better. At the same time, it is also about continuity (sustainability). Since development takes root in people and amongst people, it should have something in common with the community or society in question. Development must make sense to the people and be in line with their values and their capacity. It must be appropriate - culturally, socially, economically, 
technologically, and environmentally. Development is achieved by people and is for people. It is more than economics; it is about human development - the quality of human life as people themselves define it.

Magezi $(2007 ; 2008)$ maintains that churches are a subsystem of a community and society that people live in. Therefore, it is one of the most suitable institutions to lead development initiatives in communities. The failure of modernisation and dependency paradigms made development theories and practitioners realise that merely concentrating on theories and macro-strategies cannot bring about development. Hence, development should be more human-centred. In the late 1980s, there was a shift from the macro-theories of modernisation and dependency to a micro-approach, which focused on people and the community. Davids et al. (2005:18) added that people increasingly became the focus of development to such an extent that people-centred development became a buzz word in the 1990s and the early twenty-first century. Coetzee (1989:15-30), Theron and Barnard (1997:121-131) and many other development thinkers note that this led to the emergence of the following micro-development concepts: community development, people-centred development, participatory development and capacity building, et cetera. Humanist development views development as something more than economic growth as in the macro-theories, but should encompass the analysis of different levels, systems and structures in interaction and between society members. Its premise is that development is about people (De Beer \& Swanepoel 2000:8-20).

Churches as institutions immersed in the community and should therefore take an active role in facilitating community development. However, in the development efforts, churches tend to be fragmented and focus on their own church members. This situation has been confirmed in this study where churches belong to three main categories of mainline, Pentecostal and African Independent churches. This situation, in many respects, stifled and compromised community development efforts. James (2009a:11-12) stated that these church divisions pose a dilemma to FBOs, which is also applicable in church-driven development. Therefore, he noted that people belonging to churches implementing development initiatives tend to benefit at the expense of other community people. Furthermore, staff from such development initiatives tends to be recruited only from their own church. Thus, in church-driven development, there is sometimes a blurred line between development work and proselytising people, using the available development resources or infrastructure. It is for some of these reasons that Simms (2013) suggests, there is cause for some people to doubt the potential of communities such as churches to lead in development.

To overcome competition of churches in community projects, James (2009a:15) recommended that issues of strategy, leadership, culture, and management systems as well as clarifying the meaning of church development including its implications for the project, should be addressed. This will clarify the meaning of community development and the role to be played by the churches in respect to communities. Kelly et al. (2010) advise that the way to overcome these fragmentations and inward focus of churches is to form strong local coalitions; jointly identify community resources; undertake community level assessment and reviews; and develop and implement a joint community level initiative. The advice of Kelly et al. (2010:42-43) resonates with the findings from this study. Different churches partnered and coordinated through a community structure. The partnership was bound by a sense of equality, openness to each, unconditional regard for each other, and mutual respect. Instead of church members bickering over church followers, the coordination team stressed a sense of purpose based on vivid community needs. Commonly shared community needs became the glue that held the different churches together and steered them into focus. Shared interests provided space for strengthened collaboration. Furthermore, more and more people realised the value and strength of the church and community initiative they joined. Those who had pioneered the initiative were patient and tolerant to late project adopters. This provided a basis for a strong church and community coalition, joint resource mobilisation, project design and implementation.

Birdsall and Kelly (2005:8) point out coordination and integration of community work as one of the key challenges experienced by community organisations, particularly churches in our case. Rodriguez-Garcia et al. (2013:1-3) recommend a better alignment of community needs and strengthening of community programs, which can be done through strengthened coordination. From the study, the coordination of the churches was done through a fraternal or church committee. The committee drew people from different churches and built a sense of common purpose. The churches were bound by a common interest of addressing community needs. The coordination team communicated the vision of the community initiative as well as clarified issues and linked people to various structures. The committee addressed the concern of churches' tendency to focus on their members (James 2009b:7-9), rather than on other community people. This was done by having representation from various churches whose vision was to jointly address community needs rather than proselytising. Emphasis was placed on equality in Christ and positive regard for one another. Skills building of the coordination team were provided through the facilitator to enhance coordination and management skills. The other critical role of the coordination team was advocacy and external relations. The advocacy work of the coordinating committee indicated an important realisation, as RodriguezGarcia et al. (2013) note, that community initiatives are not a substitute for government service provision and policy implementation. To ensure sustainability of the coordination system, churches' leaderships training extended to other church leaders besides the pastor.

Many scholars and institutions in the development sector such as Kelly et al. (2010:42), Rodriguez-Garcia et al. (2013:1-3) and World Council of Churches (2010:6) lament 
the lack of prioritisation to fund community initiatives such as church-led community initiatives. While there is acknowledgement of the critical role of communities in development, funders are lukewarm regarding funding them. Birdsall and Kelly (2005:8) put it eloquently that resources are a chronic problem for community initiatives. To address this persistent challenge, Rodriguez-Garcia et al. (2013:1-3) state that there is a need to understand local social capital and the role it plays. This study revealed astonishingly high levels of community social capital of poor people helping other poor people. The social capital demonstrated in helping one another through initiatives such as search your wardrobe, food hampers, combined efforts to rehabilitate community tracks, and initiating ISALS amongst the very poor people demonstrated an alternative way of poor people's initiatives to support one another. Another important observation was the realisation of communities' capacity limitation as poor people, hence adopting a different strategy of sourcing resources externally.

Church community initiatives need not only be spiritual amongst church members and to the community, but it must be practical too. Consistent with holistic gospel ministry of Jesus Christ (Lk 4) church members engaged in practical assistance to fellow community members. They assisted with paying school fees to needy orphans and vulnerable children; constructed community health centres as well as a youth centre; assisted people with disabilities (PWD); and advocated for community needs that were beyond their reach. People who do not belong to any church were fully integrated in the community development initiatives.

Rodriguez-García et al. (2013:1-3) in their conclusion of the World Bank and DfID evaluation study on the role of communities, note that there is need for a continuous process of knowledge building about what works and what does not work concerning communities. They wisely state that community responses cannot be taken for granted nor can they be guaranteed. However, what I find disturbing is what I would call a 'big miss' on how grassroots communities function in their recommendations for policy and programing. They stated that there needs to be a shift from support of doing a bit of everything with good intentions to support for doing what can be done best with quality. This recommendation reflects the top-down approach adopted in many cases by donors and international organisations. The recommendation is based on a misunderstanding of how communities operate, particularly in rural Africa. Community needs are integrated. HIV, OVC, disability, need for food, livelihood, et cetera affect people in multifaceted ways, particularly vulnerable households. One cannot have the luxury of focusing on one aspect at the neglect of other issues in order to deliver quality. Community interventions should be holistic. Health interventions lead to livelihoods, OVC and advocacy and vice versa. This recommendation, after such a magnificent study, suggests the need for further studying the dynamics of grassroots community interventions.
Notably, James' (2009b:12-13) FBO typologies, UNAIDS categorisation of FBOs cited by Samuels et al. (2010:1-4) and Magezi's (2012:4-5) typology of churches' work in community health are elementary efforts towards a robust study on the work of FBOs and churches as community institutions. In this situation, the advice of Mati (2013) in the form of a lament to subjected FBOs and churches work to rigorous social scientific analysis should be heeded. While there are clear factors that contribute to churches' success in community development as indicated on the thematic map (Figure 1), there is a serious information gap regarding the empirical study of churches' work in development at a fairly large scale. An examination of this nature can only be done through a practical inquiry approach (Göran n.d.; Stevenson 2005). Stevenson (2005) advises that while practical theory is not generalisable in the traditional sense, it mirrors case law in offering a precedent that can be tested in relation to new situations. Practical inquiry generates knowledge for local people as well as general practice. Further longitudinal examination of churches' work in development would provide additional insights on how development is done through churches in the communities.

\section{A church-driven development model}

A number of considerations should be taken in developing a church-driven development model. These include the following seven considerations: an understanding that churches are generally divided over theological and doctrinal positions; there is a general inclination of churches to prioritise serving their church members over other community members; there is sometimes a tendency for churches to use development resources to proselytise people and further their churches' interests; church leaders have limited capacity to effectively lead and implement community development activities; churches sometimes perform an ambivalent role in communities - for instance in gender development initiatives, churches can either play a constructive or destructive role. Churches may fan negative practices through certain biblical interpretations about the position of women; a church is a subsystem of the community; therefore, the challenges and experiences of its members are most likely the same as those of the rest of the community; and churches are not usually preferred by donors to lead community projects (James 2009a:6).

With these considerations in mind, a holistic model is hereby proposed. The model is holistic in the following ways: firstly, it integrates church and community members in community development initiatives. Secondly, and most important, it considers the challenges experienced by community people as interconnected and interplaying to worsen the suffering of poor people. Therefore, a responsible response should be multifaceted:

- Jointly determinecommunityneedsthroughrepresentatives from all churches as well as community leaders. A churches' coordination team should lead this process. 
- Envision churches and communities through a participatory needs assessment as well as community vision building on the role that can be played in helping their fellow human beings. Focus should be on community assets and potential.

- Recognise the integrated needs of the community and develop prioritised multiple response strategies. Community responses cannot be fragmented but must be holistic. Ensure communities remain energised through accomplishment of one priority task and then proceed to the next. These milestones are community confidence builders as they are evidence of what they can do.

- Manage denominational or church strife as a priority threat. Individualistic and selfish motives of some churches should be changed through focusing on real community needs. Any difference or different views should be addressed patiently, graciously and in a mutually respectful way. The goal of addressing community needs should be the focal priority.

- Establish an impartial church and community coordinating team that is bound by the end of responding to community needs, to avoid tendencies of churches channelling development resources to their church members. Effective coordination is a critical component of church community interventions. It avoids destructive competition amongst churches as well as potentially advantaging particular people aligned to certain churches at the expense of deserving needy people. The role of the coordination team should be clarified in that regard.

- Develop clear approaches to motivate and generate resources from community people to assist their fellow human beings - from poor to poor initiatives in the community. Big donor projects, while respected, should not be allowed to disrupt these people-centred initiatives existing in the community.

- Develop further approaches to harness external resources from existing networks to complement community efforts. Community responses are not a substitute to government service provision. Therefore, the community strategy should incorporate an advocacy component to give voice to the community's poor.

- Coordinating teams should be patient with churches and community people who take a long time to join the community initiative due to scepticism.

- Success of church-driven development cannot be taken for granted. A thorough process of self-definition and systematic exploration of practical means of doing businesses 'in the communities' real-life situation' should be done. A practical inquiry skill should be learnt for that purpose.

\section{Conclusion}

This article proposed an approach to bring different churches in a community together to effectively participate in holistic community development initiatives. A holistic approach responds to integrated community needs without focusing on one single issue. Churches, as sub-systems of communities, lead this approach. The article is informed by the increasing global focus on involving communities in development initiatives. Churches are key community institutions, yet their role in community development is not well understood. Therefore, a cross-sectional empirical assessment study of a church-driven community development initiative that has been implemented in line with practical inquiry approach was done. The findings of the study are presented and discussed with a view to propose a church-driven approach. Finally, a holistic church-driven development approach is proposed.

\section{Acknowledgements Competing interests}

The author declares that he has no financial or personal relationships which may have inappropriately influenced him in writing this article.

\section{References}

Anderson, M.B., 1996, Development and social diversity, Oxfam, London.

Babbie, E. \& Mouton, J., 2003, The practice of social research, Oxford University Press, Cape Town.

Birdsall, K. \& Kelly, K., 2005, Community responses to HIV/AIDS: An audit of AIDSrelated activity in three South African communities, Centre for AIDS Development Research \& Evaluation, Johannesburg.

Cloete, P., Groenewald, C. \& Van Wyk, M., 1996, People first: A practical guide to community development, University of Stellenbosch, Stellenbosch.

Coetzee, J.K. (ed.), 1989, Development is for people, Southern books, Johannesburg.

Colorado State University, 2016, Case studies, definition and overview, viewed 13 May 2016, from http://writing.colostate.edu/guides/page.cfm?pageid=1285\&guideid=60

Crowe, S., Cresswell, K., Robertson, A., Huby, G., Avery, A. \& Sheikh, A., 2011, The case study approach. BMC Medical Research Methodology 11, 100. https://doi.org/ 10.1186/1471-2288-11-100

Davids, I., Theron, F. \& Maphunye, K.J. (eds.), 2005, Participatory development in South Africa: A development management perspective, Van Schaik, Pretoria.

De Beer, F. \& Swanepoel, H. (eds.), 2000, Introduction to development studies, 2nd edn., Oxford University Press, Cape Town.

Foster, G., 2010, Faith untapped: Linking community-level and sectoral health and HIV/AIDS responses, in The United States President's Emergency Plan for AIDS Relief, viewed 10 February 2015, from http://www.pepfar.gov/documents/ organization/195614.pdf

Göran, G., n.d., Practical inquiry as Action Research and Beyond, 16th European Conference on Information Systems, viewed 1 September 2017, from https://pdfs. semanticscholar.org/0b1f/3a43d914b654b49c3a0620f5e9aa30d44d67.pdf

James, R., 2009a, What is distinctive about FBOs? How European FBOs define and operationalise their faith, Praxis Paper 22, International NGO Training and Research Centre, Oxford.

James, R., 2009b, Faith-based organisational development (OD) with churches in Malawi, Praxis Note No. 47, International NGO Training and Research Centre, Oxford.

Kelly, K., Asta, R. \& Stern, R., 2010, Community entry points: Opportunities and strategies for engaging community supported HIV/AIDS prevention responses, Centre for AIDS Development, Research and Evaluation, Johannesburg.

Kotze, D.A. (ed.), 1997, Development, administration and management: A holistic approach, Van Schaik, Pretoria.

Magezi, V., 2007, HIV and AIDS, poverty and pastoral care \& counselling: A homebased and congregational systems ministerial approach in Africa, Sun Media, Stellenbosch.

Magezi, V., 2008, 'Possibilities and opportunities: Exploring the Church's contribution to fostering National Health and well-being in South Africa', Practical Theology in South Africa 23(3), 261-278.

Magezi, V., 2012, 'From periphery to the centre: Towards repositioning churches for meaningful contribution to public health care', HTS Teologiese Studies/Theological Studies 68(2), Art. \#1312, 8 pages. https://doi.org/10.4102/hts.v68i2.1312

Marshall, C. \& Rossman, G.B., 2006, Designing qualitative research, 4th edn., Sage Publications, Thousand Oaks, CA.

Mati, J.M., 2013, Bringing back 'Faith' in discourses of African Civil Society: Views from a convening in Nairobi, ISTR Africa Network Regional Conference, Nairobi, July 2013, pp. 11-13, viewed 20 January 2017, from http://c.ymcdn.com/sites/www. istr.org/resource/resmgr/africa2013/bringing_back_faith_in_disco.pdf

Maxwell, J.A., 2005, Qualitative research design: An Interactive approach, 2nd edn. Sage Publications, Thousand Oaks, CA.

Mushore, T.D., Mudavanhu, C. \& Makovere, T., 2013, 'Effectiveness of drought mitigation strategies in Bikita District, Zimbabwe', International Journal of Environmental Protection and Policy 1(4), 2013, 101-107. https://doi.org/ 10.11648/j.ijepp.20130104.19 
Parry, S., 2003, Responses of the Faith-Based Organisations to HIV/AIDS in Sub Saharan Africa, World Council of Churches Ecumenical HIV/AIDS Initiative in Africa (EHAIA), viewed 1 May 2015, from http://www.wcc-coe.org/wcc/what/mission/ (EHAIA), viewed

Peters, D.H., Taghreed, A., Olakunle, A., Akua, A.I. \& Nhan, T., 2014, 'Implementation research: What it is and how to do it', Journal of Sports Medicine 48, 731-736. https://doi.org/10.1136/bmj.f6753

Rodriguez-Garcia, R., Bonnel, R., Wilson, D. \& N'Jie, N., 2013, Direction in development Investing in communities achieves results-Findings from an evaluation of community responses to HIV and AIDS, World Bank, Washington, DC. https://doi. org/10.1596/978-0-8213-9741-1

Rubin, H.J. \& Rubin, I., 1986, Community organizing and development, Merrill Publishing, London.

Samuels, F., Geibel, R. \& Perry, F., 2010, Collaboration between faith-based communities and humanitarian actors when responding to HIV in emergencies, Project Briefing, No 41, Overseas Development Institute, London.

Simms, B., 2013, 'World Bank: Harnessing civil society expertise in undertaking and disseminating research findings', AIDS Care 25 (Suppl. 1), 1-3. https://doi.org/ $10.1080 / 09540121.2012 .733334$
Stevenson, C., 2005, 'Practical inquiry/theory in nursing', Journal of Advanced Nursing 50, 196-203. https://doi.org/10.1111/j.1365-2648.2005.03379.x

Theron, F. \& Barnard, D., 1997, 'Participation and development planning', In S Liebenberg \& P. Steward (eds.), Participatory development management and the RDP, pp. 121-131, Jutam, Cape Town.

UNAIDS, 2014, Community action towards ending the AIDS Epidemic by 2030, ESA CSO Community Dialogue on Ending AIDS and Sustaining the Community Response, Johannesburg, South Africa, pp. 22-24.

Woolsey, K. \& Biebel, K., 2007, Implementation research: The black box of program implementation, viewed 1 September 2017, from https://www.umassmed.edu/ globalassets/center-for-mental-health-services-research/documents/productspublications/issue-briefs/rehab/implementation-research_-the-black-box-ofprogram-implementation.pdf

World Council of Churches, 2010, Health system strengthening: Focus on Church based pharmaceutical human resources, Contact Magazine no 189, JanuaryMarch 2010, A publication of the World Council of Churches, viewed 15 April 2015 , March 2010, A publication of the World Council of Ch
from http://wcc-coe.org/wcc/news/contact.html

Zimbabwe Vulnerability Assessment Committee (ZimVac), Rural Livelihoods Assessment 2010 Assessment Report viewed 01 September 2017, from sodraafrikaidag.se/wp-content/uploads/2010/.../Zimvac-2010-report.pdf 